\title{
ELIMINATION OF Cucumber Mozaic Virus (CMV) FROM A RANGE OF CHRYSANTHEMUM CULTIVARS THROUGH MERISTEM CULTURE FOLLOWING HEAT TREATMENT
}

\author{
Kurniawan Budiarto \\ Indonesian Ornamental Crops Research Institute \\ Jl. Raya Pacet-Ciherang, PO. Box. 8 SDL, Cianjur, West Java, Indonesia \\ E-mail: bud1arto@yahoo.com
}

\begin{abstract}
Elimination of Cucumber Mozaic Virus (CMV) from a Range of Chrysanthemum Cultivars through meristem culture following heat treatment. Cucumber Mosaic Virus (CMV) is one of pathogenic viruses that commonly found and has caused significant losses in many chrysanthemum growers in Indonesia. Efforts have been made to get healthy plant source through eliminating virus from infected plants and one of the promising methods was the combination of thermotherapy and meristem culture. The research was conducted to find out the effect of meristem culture following heat treatments on the existence of CMV in infected chrysanthemum plantlets. The experiment was carried out in the laboratory of tissue culture and virology at The Indonesian Ornamental Crops Research Institute (IOCRI) from August 2007 until June 2008. A complete factorial with ten replications was designed to accomplish the combination of two factors. The first factor was three chrysanthemum cultivars, namely Stroika, Dewi Sartika and White Fiji, while the second dealt with the durations of heat treatment i.e. one, two and three weeks. The results showed that plantlet survival decreased, yet improved plantlet performance by faster bud initiation with lengthened heat duration. The percentage of virus-free planlets also increased along with the duration of treatment and three weeks heat treatment followed by meristem culture effectively eliminated CMV from infected planlets.
\end{abstract}

Key words: Dendranthema grandiflora, cultivar, Cucumber Mosaic Virus (CMV), elimination, thermotherapy treatment, meristem culture

\begin{abstract}
ABSTRAK
Eliminasi Virus Mosaik Mentimun (CMV) pada beberapa kultivar krisan melalui perlakuan pemanasan dan kultur meristem. Virus mosaik mentimum (CMV) merupakan salah satu patogen yang banyak ditemukan dan mengakibatkan kerugian ekonomi yang signifikan pada pertanaman krisan komersial di Indonesia. Salah satu upaya untuk mengendalikan serangan CMV adalah dengan teknik eliminasi virus pada tanaman terinfeksi guna menghasilkan tanaman bebas virus. Penelitian ini bertujuan untuk mengetahui pengaruh pemanasan dengan durasi berbeda yang diikuti dengan kultur meristem terhadap keberadaan CMV pada tanaman krisan terinfeksi. Penelitian dilakukan di Laboratorium Virologi, Balai Penelitian Tanaman Hias dari bulan Agustus 2007 hingga Juni 2008. Penelitian menggunakan Rancangan Acak Lengkap pola faktorial dengan 10 ulangan. Faktor pertama adalah tiga varietas krisan terinfeksi yaitu : Stroika, Dewi Sartika dan White Fiji; sedangkan faktor kedua adalah durasi pemanasan, yaitu 1, 2 dan 3 minggu. Hasil penelitian menunjukkan bahwa tingkat kematian planlet meningkat seiring dengan lamanya durasi pemanasan. Namun demikian, performa pertumbuhan pada planlet hasil subkultur dan persentase planlet bebas virus justru meningkat seiring dengan lamanya durasi pemanasan. Tiga minggu pemanasan yang disusul dengan kultur meristem memberikan persentase hasil planlet bebas virus tertinggi.
\end{abstract}

Kata kunci: Eliminasi, kultur meristem, krisan, kultur meristem, perlakuan pemanasan, virus mosaik mentimum (CMV)

\section{INTRODUCTION}

Chrysanthemum production in Indonesia has faced some problems in last few years. One constraint that has made significant declining of productivity and economic losses was systemic diseases caused by virus, viroid and phytoplasmic organisms. There were at least 14 viruses that have been reported to infect chrysanthemum, such as chrysanthemum latent virus, cucumber mosaic virus, chrysanthemum virus B, chrysanthemum ring-spot virus and chrysanthemum rosette virus (Megan et al., 2001). In Indonesia, a side 
from Chrysanthemum Virus B (CVB), Cucumber Mosaic Virus (CMV) is one of the most commonly viruses found in commercial growers and have given significant losses up this moment (Rahardjo et al., 2005).

CMV is taxonomically belongs to cucumovirus from the family of Bromoviridae (Brunt et al., 1996). The virus particle was icosahedral-formed with the diameter of 28-29 nm. Tripartite genome consisted of single-stranded and linear RNA with the size of 3389 kb, $3035 \mathrm{~kb}$ and $2197 \mathrm{~kb}$. The nucleocapsid (virion) was isometric, rounded in profile without protein envelop and a conspicuous capsomere arrangement (Roossinck, 2002). Particle molecule was approximately 5.8 to 6.7 millions in weight comprised of $82 \%$ protein and $18 \%$ nucleic acid (RNA), specifically $24 \%$ G, 23\% A, 23\% C, 30\% U (Owen et al., 1990). This virus was a broad host range, consisted of more than 1000 species i.e. nicotiana (Walkey \& Cooper, 1975), lilium (Liliaceae), dendrobium, calalily (Araceae), alstromeria, pelargonium and carnation (Loebenstein et al., 1995). Virus particles could be transmitted by mechanical inoculation, seed or even insects. More than 60 species of insects, including Acyrthosiphon pisum, Aphis craccivora and Myzus persicae (Aphididae) were observed naturally act as vectors of CMV. The general symptoms were varied among the infected plants ranging from symptomless to permanent degeneration of vegetatively propagated plants (Rahardjo et al., 2005).

Efforts have been made to get the healthyplant source by eliminating the virus from the infected plants. Several methods such as electrical charges, heat treatment, meristem culture and the use of synthetic antiviral have been reported successful for virus elimination in some crops. Isolation of meristematic apices was firstly reported for rescuing the cymbidium plants from CyMV (Morel, 1960). These method was then, accomplished for similar purposes in garlic, shallot, alstromeria, cassava, begonias, grapes and potato (Walkey et al., 1987; Hakkaart \& Versluijs, 1988; Adejare et al., 1987; Verma et al. 2005; Nascimento et al., 2003; Nagib et al., 2003). In other crops, however, virus free tissues were reported difficult to be isolated, since they were mostly microscopic and very sensitive (Brown et al., 1988).

Thermotherapy or heat treatment was conducted for virus elimination related with characteristic of some viruses that showed declining in multiplication rate during high temperature. These method was successfully applied in some crops on the range of $35-40^{\circ} \mathrm{C}$ (Sharma et al., 2007). In contrast, tolerance level and survival rate of the plants to the increasing temperature was also become the limiting factor as far as these concerned (Lozoya-Saldana \& Merlin-Lara, 1984).

Combination method of thermotherapy and meristem culture was subjected to encounter the technical constraints in single application of the respective techniques. The research was then, conducted to find out the effect of thermotherapy treatment in different durations followed by meristem culture on the existence of CMV in infected chrysanthemum plants.

\section{MATERIALS AND METHODS}

The research was carried out in the laboratory of tissue culture and virology at The Indonesian Ornamental Crops Research Institute (IOCRI) from August 2007 until June 2008. A Completely Randomized Design (CRD) with 10 replications was used in this experiment. The first factor was three commercial chrysanthemum cultivars, namely Stroika, Dewi Sartika and White Fiji. The second factor was duration of thermotherapy treatments i.e. one, two and three week heat treatment.

The CMV-infected cuttings collected from commercial nurseries were replanted in $15 \mathrm{~cm}$ pot and maintained in growth chamber with $16 \mathrm{~h}$ long day period. After the new leaf flushes appeared (approximately 2 weeks), the plants were pinched. The new emerging lateral growths were then served for explants. Direct shoot regeneration was conducted by planting the apical explants to $1 / 2 \mathrm{MS}+0.5 \mathrm{mg} \mathrm{l}^{-1}$ IAA and incubated in growth chamber with temperature of $16-18^{\circ} \mathrm{C}$. The shoots formed from explant cultures (approximately 10 days) were then subcultured into $1 / 2 \mathrm{MS}+0.1 \mathrm{mg} \mathrm{l}^{-1}$ IAA to obtain uniform plantlets. A week before heat treatments, the plantlets were preconditioned in incubator with the daily temperature of $30-35^{\circ} \mathrm{C}$. The temperature of incubator was then increased up to $38-40^{\circ} \mathrm{C}$ based on the treatment durations.

After heat treatments, approximately $<0.5 \mathrm{~mm}$ apical meristem was dissected under the binocular microscope, and planted into MS media containing NAA for callus induction. The callus were then subcultured into the same media and incubated into light condition for further proliferation and shoot induction. The new emerging shoots were deflasked into regeneration media to obtain complete plantlets. Randomly plantlet samples in every treatment combinations were selected for CMV rapid detection using direct ELISA method according to Clark \& Adam (1977). Direct ELISA detection was presented into the following steps : $100 \mu \mathrm{l}$ CMV IgG (AGDIA, USA) was mixed $1: 200$ with the coating 
buffer $\left(\mathrm{Na}_{2} \mathrm{CO}_{3}+\mathrm{NaHCO}_{3}+\mathrm{NaN}_{3}\right)$ and over nightly incubated in the temperature of $4^{\circ} \mathrm{C}$. The microplates were then, rinsed twice with PBS Tween $(\mathrm{NaCl}+$ $\mathrm{KH}_{2} \mathrm{PO}_{4}+\mathrm{Na}_{2} \mathrm{HPO}_{4}+\mathrm{KCl}+\mathrm{NaN}_{3}+$ Tween $20+$ $\mathrm{H}_{2} \mathrm{O}$ ) buffer in three minutes each. About $0.2 \mathrm{~g}$ of leaf samples were extracted and buffered with $1 \mathrm{ml}$ mixture of PBST $+0.02 \%$ PVP $(1: 5)$. The $100 \mu$ of leaf extracts were then, incubated for $2 \mathrm{~h}$ in $37^{\circ} \mathrm{C}$ and rinsed with PBS Tween buffer. After labeled with Alkaline Phosphatase enzyme, $100 \mu \mathrm{l}$ of IgG CVB was pipetted into microplates and mixed with ECI (PBST $+0.2 \%$ BSA) with the composition of $1: 200$. The mixture was incubated for $2 \mathrm{~h}$ in $37^{\circ} \mathrm{C}$. After $2 \mathrm{~h}$ incubation, the microplates were then rinsed with PBS Tween buffer. $100 \mu \mathrm{l}$ substrate buffer containing 4-nitrophenylphospate was put into microplates and incubated in the room temperature. After the substrate changed in color into yellow, the reactions was then ceased with $25 \mu \mathrm{l} \mathrm{NaOH}$ $3 \mathrm{M}$. Color intensities of the substrate were measured using ELISA reader (Minireader II Dynatech) on 410 nm wavelength. The plant sample was dedicated virusfree if three times of the substrate absorbent measured from the ELISA reader was less than the value of positive control. The observation was also conducted on the survival rate of plantlets after heat treatments and bud initiation after the meristem culture.

\section{RESULTS AND DISCUSSION}

Plantlet survival after heat treatments. The plantlet survival after heat treatment was highly affected by the treatment durations. However, no differences was detected among the chrysanthemum cultivars tested in every duration of thermotherapy. Number of plantlet survived of all cultivars were decreased along with lenghtening heat treatments (Table 1). This finding was not in line with the observation of Budiarto et al. (2007) because different cultivars might have different levels of tolerance to the increasing temperature and duration of heat treatment. These Fac. indicated that all the tested cultivars had the same response characteristics to high temperature, though in some cases, the genome composition of cultivars might lead to a genotype has wider range of adaptation than others to such detrimental conditions including high temperature (Nagib et al., 2003).

Table 1 also showed that the trends of plantlet death rates were similar among the cultivars tested. During the first week of heat treatments, $18-22 \%$ of treated plantlets were ceased. The conditions were slightly decreased in the following week, 12-22\% (Figure 1). The high plantlet deaths in the first week suggested that one week $30-35^{\circ} \mathrm{C}$ preconditions were not sufficient for the plantlet to make suitable adaptation on higher temperature of heat treatment. According to Manganaris et al. (2003), since the mechanical adaptation of plants was time-depended on the degree of transition in regular change, the plantlet then, should be provided sufficient precondition time with small and regular increase of temperature approaching the level heat treatment to hinder high plantlet death in the early stage.

The highest plantlet death rate was consecutively observed on the third weeks of thermotherapy treatment in all cultivars tested, for about 34-44\% (Figure 1). These higher death rates indicated the period of three weeks was critical for chrysanthemum to heat treatment. Wang et al. (2006) stated inside the culture flask or in vitro condition, a protected environment might lead to narrower adaptation of plantlets to the extreme conditions such as high temperature. Thus, the lower plant survival might be an indicator of the toleration limit of chrysanthemum to high temperature.

Table 1. Number of plantlet survived of three chrysanthemum cultivars post different thermotherapy durations

\begin{tabular}{|c|c|c|c|}
\hline \multirow{2}{*}{ Cultivars } & \multicolumn{3}{|c|}{ Average plantlet survived post to different thermotherapy durations ${ }^{*}$ (weeks) } \\
\hline & 1 & 2 & 3 \\
\hline Stroika & $8.2 \mathrm{a}^{* *)}$ & & $3.4 \mathrm{~b}$ \\
\hline Dewi Sartika & 8.4 a & 7.2 a & $2.8 \mathrm{~b}$ \\
\hline White Fiji & 7.8 а & $5.8 \mathrm{ab}$ & $2.4 \mathrm{~b}$ \\
\hline
\end{tabular}

*) number of initial planlets was 20 per replication.

**) values followed by different letters in the same row differ significantly at LSD 5\%. 
Buds initiation. The subsequent growth of plantlets was also significantly influenced by the duration of thermotherapy treatments. Buds initiation from meristem culture was observed faster in line with lengthened periods of heat treatment. Meristematic callus taken from three weeks heat treatments needed shorter period to initiate the shoot buds. Though not significantly different, similar indications were also observed from callus treated with two weeks than those of one week thermotherapy treatments (Table 2).

Slower bud initiation on the plantlets given one and two weeks heat treatment indicated that the callus development and proliferation were retarded. These suboptimal growths inferred that the plant metabolic process were still interfered with such condition, presumably virus particles remained in the tissues. Infecting sub cellularly, the virus changed the growth orientation of plantlets to produce metabolites needed by the virus for multiplication (Marwoto et al., 2004).
The situations were systemically persistent, thus the planlet were lack in metabolites and failed to support the optimal growth.

Contradictive with these conditions, the faster bud initiation on the plantlets treated by three weeks heat and meristem culture also suggested that the potential growth of plantlets were retained. The growth recovery was predicted to the declining and/or elimination of the virus particles from the plantlet tissues. Thus, the plantlets were able to absorb nutrients for metabolic processes and synthesize necessary elements for the optimal growth (Styer \& Chin, 1983).

ELISA bioassay. Direct ELISA for virus detection was spectrophotometerically revealed as absorbent values. These values indicated the existence of virus particles remained in plant tissues. The absorbent values of all chrysanthemum cultivars treated by heat

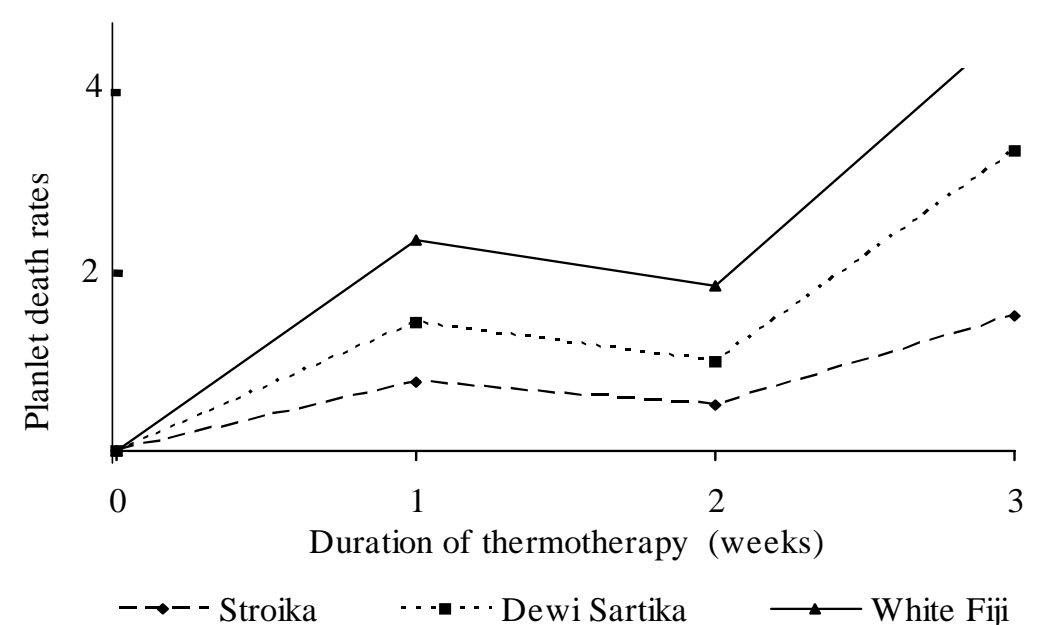

Figure 1. Planlet death rates of three chrysanthemum cultivars after one, two and three week thermotherapy treatments

Table 2. Buds initiation post meristem culture of three chrysanthemum varieties treated with different thermotherapy durations

\begin{tabular}{lccc}
\hline \multirow{2}{*}{ Cultivars } & \multicolumn{3}{c}{ Bud initiation post to different thermotherapy durations ${ }^{*}$ (days) } \\
\cline { 2 - 4 } & 1 & 2 & 3 \\
\hline Stroika & $68.4 \mathrm{a}$ & $62.8 \mathrm{a}$ & $50.4 \mathrm{~b}$ \\
Dewi Sartika & $67.2 \mathrm{a}$ & $60.3 \mathrm{~b}$ & $47.2 \mathrm{c}$ \\
White Fiji & $70.8 \mathrm{a}$ & $67.7 \mathrm{a}$ & $46.4 \mathrm{~b}$ \\
\hline
\end{tabular}

${ }^{*}$ values followed by different letters in the same row differ significantly at LSD 5\%. 
Table 3. CMV detection by direct ELISA and percentage of virus-free on three chrysanthemum cultivars treated by different durations of thermotherapy treatment

\begin{tabular}{lccc}
\hline \multicolumn{1}{c}{ Cultivars } & Thermotherapy durations (weeks) & Absorbance values & Percentage of CVB-free \\
\hline \multirow{2}{*}{ Stroika } & 1 & $0.08-0.22$ & $4 / 10(30 \%)$ \\
& 2 & $0.07-0.12$ & $6 / 10(70 \%)$ \\
\multirow{2}{*}{ Dewi Sartika } & 3 & $0.04-0.08$ & $10 / 10(100 \%)$ \\
& 1 & $0.08-0.18$ & $5 / 10(50 \%)$ \\
White Fiji & 2 & $0.05-0.14$ & $6 / 10(60 \%)$ \\
& 3 & $0.04-0.10$ & $10 / 10(100 \%)$ \\
Positive control & 1 & $0.10-0.18$ & $4 / 10(40 \%)$ \\
Negative control & 2 & $0.06-0.14$ & $8 / 10(80 \%)$ \\
\hline
\end{tabular}

therapy declined in line with lengthening of heat treatments (Table 3).

Based on the analysis of the plant tissue (Table $3)$, the percentage of CMV-free plantlets was also increase in accordance with the durations of thermotherapy treatment. One week heat treatment freed $40-50 \%$ of plantlets from CMV. The numbers then, increased up to $60-80 \%$ after treated with two weeks heat treatment while, three weeks thermotherapy followed by meristem culture successfully eliminated CMV from the infected plantlets.

The decrease of virus contamination and increasing virus free plantlets suggested that the CMV particles and their persistence in the tissue were influenced by the length of heat treatments in $38-40^{\circ} \mathrm{C}$. The remaining virus particles detected on the plantlet tissues of one and two weeks therapy indicated that these durations were not sufficient to free meristematic apices from virus particles. While conversely, three weeks treatment could successfully prevent virus multiplications in this highly mitotic area. Thus, the isolated meristem then, optimally proliferated and formed virus-free plantlets (Hosokawa et al., 2004).

Combination of heat treatment and meristem culture to eliminate CVM from infected chrysanthemum has been successfully conducted, though some constraints should still be couped up with i.e tolerance level of plant being exposed to high temperature in a certain period. Thus, it has also been suggested to improve plant physiological performance before conducting the thermotherapy.

\section{CONCLUSIONS}

All chrysanthemum cultivars responded similarly to the duration of thermotherapy treatments. Plantlet survival decreased with the lengthened period of heat treatment. Bud initiation from callus was fastened after the plantlet treated by longer heat treatments. Percentage of virus-free plantlets increased consecutively with the duration of treatments and three weeks heat treatment followed by meristem culture effectively eliminated CMV from the infected plantlets.

\section{REFERENCES}

Adejare GO, Gupta SD \& Ghosh PD. 1987. Eradication of cassava mosaic disease from Nigerian cassava (Manihot esculenta) clones by meristem tip culture. Plant Cell Tiss. and Organ Cult. 1: 2532.

Brown CR, Kwiatkowski S, Martin MW \& Thomas PE. 1988. Eradication of PVS from potato clones through excisions of meristems from in vitro, heat treated shoot tips. Am. J. Pot. Res: 633-638.

Brunt AA, Crabtree K, Dallwitz MJ, Gibbs AJ, Watson L \& Zurcher EJ. 1996 onwards. Plant Viruses Online : Descriptions and lists from the VIDE database. Ver. 20th. http://biology.anu.edu.au/ 
Groups/MES/vide/. Referred in 27 February 2007.

Budiarto K, Sulyo Y, Rahardjo IB \& Pramanik D. 2007. Pengaruh durasi pemanasan terhadap keberadaan Chrysanthemum virus $B$ pada tiga varietas krisan terinfeksi. AGRITEK. 15(3): 537-543.

Clark MF \& Adam AN. 1977. Characteristic of the microplate method of enzyme lingked immunosorbent assay for the detection of plant viruses. J. Gen. Virol. 34: 475-483.

Hakkaart FA \& Versluijs JMA. 1988. Virus elimination by meristem tip culture from a range of Alstromeria cultivars. Plant. Dis. 68: 216-218.

Hosokawa MA, Otake A, Ohishi K, Ueda E, Hayashi T \& Yazawa S. 2004. Elimination of chrysanthemum stunt viroid from an infected chrysanthemum cultivar by shoot regeneration from a leaf primordium-free shoot apical meristem dome attached to a root tip. Plant Cell Rep. 22: 859-863.

Loebenstein G, Lawson LH \& Brunt AA. 1995. Virus and Virus-Like Diseases of Bulb and Flower Crops. John Wiley \& Sons. New York.

Lozoya-Saldana H \& Merlin-Lara O. 1984. Thermotherapy and tissue culture for elimination of potato virus $X$ (PVX) in Mexican potato cultivars resistant to late blight. Am. J. Pot Res. 61:735- 739 .

Manganaris GA, Economou AS, Boubourakas \& Katis NI. 2003. Elimination of PPV and PNRSV through thermotherapy and meristem-tip culture in nectarine. Plant Cell Rep. 22: 195-200.

Marwoto B, Sanjaya L, Budiarto K \& Rahardjo IB. 2004. Pengaruh antiviral dalam media kultur terhadap keberadaan chrysanthemum virus B pada 4 varietas krisan terinfeksi. J. Hortikultura. (ed. khusus) 14: 410-418.

Megan FH, Giles RJ, Moran RM \& Hepworth G. 2001. The incidence of chrysanthemum stunt viroid and chrysanthemum $B$ carlavirus, tomato aspermy cucumovirus and tomato spotted wilt tospovirus in Australian chrysanthemum crops. Australas. Plant Pathol. 25(3): 174-178.

Morel G. 1960. Producing virus free-Cymbidium. Am. Orchid Soc. Bull. 29: 495-497.

Nagib A, Hossain SA, Alam MF, Hossain MM, Islam R \& Sultana RS. 2003. Virus free potato tuber seed production through meristem culture in tropical Asia. Asian J. Plant. Sci. 2(8): 616-622.

Nascimento LC, Riberio GP, Willadino L \& Andrade GP. 2003. Stock indexing and potato virus $Y$ elimination from potato plants cultivated in vitro. Sci. Agric. 60(3): 525-530.

Owen JE, Shintaku M, Aeschleman P, Tahar SB \& Palukaitis P. 1990. Nucleotide sequences and evolutionary relationship of cucumber mosaic virus (CMV) strains : RNA 3. J. Gen. Virol. 71: 2243-2249.

Rahardjo IB, Muharam A \& Sulyo Y. 2005. Studi pembuatan antiserurn poliklonal untuk deteksi cepat virus mosaik mentimun pada krisan. $J$. Hortikultura 15(2): 124-128.

Roossinck MJ. 2002. Evolutionary history of cucumber mosaic virus deduced by phylogenetic analyses. J. Virol. 76: 3382-3387.

Sharma S, Singh SB, Rani G, Zaidi AA, Hallan V, Nagpal A \& Virk GS. 2007. Production of Indian citrus ringspot virus free plants of Kinnow employing chemotherapy coupled with shoot tip grafting. $J$. Cent. Eur. Agric. 8(1): 1-8.

Styer DJ \& Chin CK. 1983. Meristern and shoot tip culture for propagation, pathogen elimination and germplasm preservation. Hortic. Rev. 5: 221-277.

Verma NR, Ram R \& Zaidi AA. 2005. In vitro production of prunus necrotic ringspot virus-free begonias through chemo- and thermotherapy. Scientia Hort. 103: 239-247.

Walkey DGA \& Cooper VC. 1975. Effect of temperature on virus eradication and growth of 
infected tissue cultures. Ann. Appl. Biol. 80(2): 185-190.

Walkey DGA, Webb MJW, Bolland CJ \& Miller A. 1987. Production of virus free garlic (Allium sativum L.) and shallot (Allium ascalonicum L.) by meristern tip culture. J. Hort. Sci and Biotech. 62(2) : 211- 220.

Wang I, Wang G, Tang NHR, Deng X \& Zhang H. 2006. Effect of thermotherapy on elimination of apple stem grooving virus and apple chlorotic leaf spot virus for in vitro-cultured pear shoot tips. J. Amer. Soc. Hort. Sci. 41(3): 1327-1329. 